Journal of Mathematics and Statistics 8 (1): 154-156, 2012

ISSN 1549-3644

(C) 2012 Science Publications

\title{
Artificial Shortages and Strategic Pricing
}

\author{
Mouataz Zreika and Partha Gangopadhyay \\ United Enterprise Group \\ Economics and Finance, Faculty of Business \\ University of Western Sydney, Parramatta Campus, Locked Bag \\ 1797, Penrith South DC, NSW 1797, Australia
}

\begin{abstract}
Problem statement: We consider a monopolist who manipulates the market by artificially creating shortages that result in an increase in current price that, in turn, boosts demand for the product in subsequent periods. The approach is to develop an intertemporal model of pricing strategy for a monopolist. Approach: The postulated pricing strategy creates an incentive for producers to reduce current supply and raise current prices and sacrifice current profits in order to increase future profits. The main problem is to explain the precise mathematical conditions under which the pricing strategy will be chosen by a monopolist. Results: We derive the optimal pricing strategy to argue that the monopolist has an incentive to adopt simple market manipulation that calls forth a close examination of issues concerning deregulation. Conclusion: The paper examines two possible strategies for a typical monopolist-strategic pricing vis-a-vis a myopic pricing. The intuition is that the monopolist can manipulate the market by artificially creating shortages that result in an increase in current price that, in turn, boosts demand for the product in subsequent periods.
\end{abstract}

Key words: Strategic pricing, market manipulation, myopic pricing, subsequent periods, typical monopolist, possible strategies, pricing strategy, artificially creating, current supply

\section{INTRODUCTION}

In some markets current shortages not only raise current prices but can also influence future demand and, thereby, future prices(The shortage of electricity in California has proved profitable for power companies and evidence is mounting that Californian power companies have been rigging electricity prices. We now know that such rigging of electric prices took place in Britain before 1996 (Gangopadhyay and Chatterji, 2000). This possibility creates an incentive for producers to reduce current supply and raise current prices and sacrifice current profits to increase future profits (This type of non-myopic pricing strategy has been examined in the literature: the experience curve phenomenon of falling marginal costs associated with accumulated output or production experience can create incentives for strategic pricing-as opposed to myopic pricing (Riordan, 1986). It is generally recognised that optimal pricing strategies will depend on the anticipated nature of the dynamic cost, or demand, functions as noted in the context of forecasting and determining monthly and seasonale variations in Air Pollutants Index (Lee et al., 2012a). What is novel in this study is the positive effect of a current price increase on future demand. It is possible to explain such a positive effect in two ways: first, if price rise creates an element of panic among buyers. Secondly, current price increases can boost future demand if prices signal product quality with asymmetrically informed buyers). Such manipulations raise thorny questions about the onslaught of deregulation in 1990s and the tenability of our unprecedented trust in the market mechanism. Economic crises in Asia and power crisis in California are amongst many that will evoke a serious debate on the pros and cons of our increased faith in markets (Gangopadhyay and Chatterji, 2005; El-Salam, 2011). This note offers a simple scheme of strategic pricing for a monopolist who creates artificial shortages to manipulate future prices. Such a pricing scheme can easily be sustained even in an oligopoly.

Model: The market unfolds for two periods-period $\mathrm{t}$ and $t+1$. The inverse demand function of the monopolist for the product in period $t$ is assumed to be linear and given as:

$P_{t}=a-b Q_{t}$

where, $P_{t}$ and $Q_{t}$ are price and quantity respectively in period $t$ and $a, b>0$.

It is assumed that the marginal cost and average cost are zero. The myopic price and the corresponding quantity 
in period $\mathrm{t}$ are defined as $\mathrm{P}_{\mathrm{t}}^{\mathrm{M}}$ and $\mathrm{Q}_{\mathrm{t}}^{\mathrm{M}}$ that maximise instantaneous profit in period t. Given the demand function (1a) and zero cost, we derive them as:

$\mathrm{P}_{\mathrm{t}}^{\mathrm{M}}=\mathrm{a} / 2$

$\mathrm{Q}_{\mathrm{t}}^{\mathrm{M}}=\mathrm{a} /(2 \mathrm{~b})$

Myopically-maximised profit in period $\mathrm{t}$ is $\Pi_{\mathrm{t}}^{\mathrm{M}}$ :

$\Pi_{\mathrm{t}}^{\mathrm{M}}=\mathrm{a}^{2} /(4 \mathrm{~b})$

We define $p>0$ as the increase in price from $\mathrm{P}_{t}^{\mathrm{M}}$ caused by an artificial shortage in period t:

$\mathrm{p}=\mathrm{P}_{\mathrm{t}}-\mathrm{P}_{\mathrm{t}}^{\mathrm{M}}$

We assume the inverse demand function in period $\mathrm{t}+1$ to be:

$P_{t+1}=a-b_{1} Q_{t+1}$

$\mathrm{b}_{1}=\mathrm{b} /(\mathrm{Hp}+1)$

Equation (2c) incorporates the effect of price increase from $\mathrm{P}_{\mathrm{t}}^{\mathrm{M}}$ in period $\mathrm{t}$ on the demand function in period $t+1$. This is how we connect period $t$ and $t+1$ that gives rise to the incentive to strategise the pricing decision. If the monopolist adopts the myopic profitmaximising price in period $\mathrm{t}$, the demand function remains invariant through time. Hence, the myopicallymaximised profit in period $t+1$ is the same as above:

$\Pi_{t+1}{ }^{M}=a^{2} /(4 b)$

If the time rate of discount of the monopolist is $\delta$, then the two-period profits from myopic optimisation are $\Sigma^{\mathrm{M}}$ :

$\Sigma^{\mathrm{M}}=\mathrm{a}^{2}(1+\delta) /(4 \mathrm{~b})$

\section{MATERIALS AND METHODS}

The strategic pricing of the monopolist entails the adoption of $\mathrm{p}$ in period $\mathrm{t}$ that influences the demand function in period $t+1$ and then he sets the monopoly price in period $t+1$ with the new demand function characterised by (2b) and (2c). By so doing the monopolist loses profits in period $t$ for extra profits in period $t+1$. We design the conditions that will guarantee the strategic pricing to bring more profits than profits from myopic prices.

We define $\Pi_{t}{ }^{S}$ as the profit from the price increase (p) in period $t$ and $\Pi_{t+1} s$ as the profit from the strategic pricing in period $t+1$. The strategic pricing in period $t+1$ is the same as the myopic pricing with the new demand function characterised by (2b) and (2c).

\section{RESULTS}

We present the main results in the following propositions.

Proposition 1: The strategic pricing will always Pareto-dominate the myopic pricing strategy so long as $\mathrm{H}>1 / \mathrm{p}$.

Proof: The period t profit from the strategic pricing is:

$\Pi_{\mathrm{t}}^{\mathrm{S}}=\left[\left(\mathrm{a}^{2} / 2+\mathrm{pa}\right)-(\mathrm{a} / 2+\mathrm{p})^{2}\right] /(2 \mathrm{~b})$

We get the above by substituting (2a) into (1a) and then multiplying the resultant price by the quantity. We now derive the myopic price and quantity in period $t+1$ - with the new demand function - and multiply them to yield the profits from strategic price in period $t+1, \Pi_{t+1} s$ :

$\Pi_{\mathrm{t}+1} \mathrm{~s}=\mathrm{a}^{2} /\left(4 \mathrm{~b}_{1}\right)=(1+\mathrm{Hp}) \mathrm{a}^{2} /(4 \mathrm{~b})$

The two-period profits from the strategic pricing, $\Sigma^{\mathrm{S}}$, is derived as:

$\Sigma^{\mathrm{S}}=\left[\left(\mathrm{a}^{2} / 2+\mathrm{pa}\right)-(\mathrm{a} / 2+\mathrm{p})^{2}\right] /(2 \mathrm{~b})+\delta(1+\mathrm{Hp}) \mathrm{a}^{2} /(4 \mathrm{~b})$

The strategic pricing will yield higher profits than myopic pricing if:

$\Sigma^{\mathrm{S}}-\Sigma^{\mathrm{M}}>0$

Substituting (3a) and (3d) into (4a) yields:

$\Pi_{\mathrm{t}}^{\mathrm{S}}+\left[\left(\delta \mathrm{a}^{2}\right) *(\mathrm{Hp}-1) /(4 \mathrm{~b})\right]>0$

The sufficient condition for satisfying (4b) is:

$\mathrm{H}>1 / \mathrm{p}$

Thus the monopolist has an incentive to create an artificial shortage in period $t$ to influence the demand function in period $t+1$ since the strategic pricing yields a higher profit than the overall profit from myopicallyoptimal prices. This is true if the boost in demand in period $t+1$ is sufficiently strong $(H>1 / p)$ to outweigh the loss of choosing $\mathrm{p}$ in period $\mathrm{t}$. We turn to determine the strategic price increase, $p$, that maximises the overall profits. This is offered in Proposition 2.

Proposition 2: The strategic price increase in period t that maximises the discounted stream of profits of the monopolist is given as $\mathrm{p}^{*}$ : 
$\mathrm{p}^{*}=\left(\delta \mathrm{Ha}^{2}\right) /(4 \mathrm{~b})$

Proof: We get (4d) by differentiating (3d) with respect to $\mathrm{p}$ and setting it equal to zero and the second order condition is satisfied since $b>0$. QED.

\section{DISCUSSION}

Two possible pricing strategies of a typical monopolist are examined. Can the strategic pricing dominate a myopic pricing strategy? The paper provides an answer to the question by constructing a simple linear model, which is a new finding in the context of strategic pricing of a single seller in a market.

\section{CONCLUSION}

The note examines two possible strategies for a typical monopolist - strategic pricing vis-a-vis a myopic pricing - in an extremely simple model. The intuition is that the monopolist can manipulate the market by artificially creating shortages that result in an increase in current price that, in turn, boosts demand for the product in subsequent periods (Krugman, 2000; Lee $e t$ al., 2012b). We show that the monopolist has an incentive to adopt such manipulation that calls forth a close examination of issues concerning deregulation. It would be important to extend this note to rationalise inequality (4c) by introducing either panic elements, or asymmetric information about product quality.

\section{ACKNOWLEDGEMENT}

We are grateful to the Science Publications for sponsoring our research. The responsibility of errors is exclusively ours.

\section{REFERENCE}

El-Salam, M.E.A, 2011. A modification of the ridge type regression estimates. Am. J. Applied Sci, 8: 97-102. DOI: 10.3844/ajassp.2011.97.102

Gangopadhyay, P. and M. Chatterji, 2005. Economics of Globalisation. 1st Edn., Ashgate, Aldershot, ISBN: 0754641376 pp: 314.

Krugman, P., 2000. California Screaming. 1st Edn., The New York, Times, pp: 12-10.

Lee, M.H., Rahman, N.H., Suharto, Latif, N.T., Nor, M.E., Kamisan, N.A. 2012a. Seasonal ARIMA for Forecasting air Pollution Index: A Case Study. Am. J. Applied Sci, 9: 570-578.

Lee, M.H., Nor, M. E., Suharto, Sadei, H.J., Rahman, N.H.A, Kamisan, N.A. 2012b. Fuzzy time series: An application to tourism demand forecasting. Am. J. Applied Sci, 991): 132-140. DOI: 10.3844/ajassp.2012.132.140

Riordan, M.H., 1986. Monopolistic competition with experience goods. Q. J. Econ., 11: 108-130. 